\title{
Why Independent Inventors Never Quit? \\ In Search of Contribution of Inventive Outcomes on \\ Subjective Success of Independent Inventors
}

\author{
C. N. WICKRAMASINGHE \\ Department of Commerce and Financial Management \\ University of Kelaniya, Sri Lanka \\ nalakacw@yahoo.com \\ N. AHMAD AND S. RASHID \\ Faculty of Human Ecology, University Putra Malaysia, Serdang, Selangor, Malaysia \\ nobaya@putra.upm.edu.my/sharifah@putra.upm.edu.my
}

\begin{abstract}
Modern technological development of the modern society has been evaluated by the number of patents, commercialization and economic gains of technological innovations. Hence, the success of inventors has been purely measured by the objective measures of the invention process outcomes. Even though, this approach agreed with elite organizational inventors, independent inventors of a society are more humanitarian than the organizational inventors. Hence, the pure objective outcome measures were unable to address the question of why independent inventors continue in inventive activities even they are not objectively successful. Previous studies on the independent inventors has not focused on the social and psychological factors. Hence, the understanding of the subjective outcomes of inventive activities have remained unexplained. Along with the traditional objective outcome measures, the present study explains the inventive career satisfaction and sense of inventive community as two subjective outcomes of the inventive activities of independent inventors in Sri Lanka. It explores how the objective outcomes and subjective outcomes of the inventive life relates to the ultimate global happiness and satisfaction of the life of the independent inventors.
\end{abstract}

Key Words: Technology, Inventors, Success, Sri Lanka, Social Psychology, Happiness

\section{Introduction}

Success is the ultimate aim of every human endeavor. Everyone in the society wants to achieve success, but the success is a different thing for different people. 
Hence, the success is a complicated but essential concept that explains the human behavior. In technological innovation industry also there are ultimate desires to achieve successful inventions and innovations. In modern knowledge economy, from independent inventors to CEOs of the multinational innovative companies are expected to be successful in innovation process. Commercial biasness of the modern innovation industry has indicated that efficient development of profitable product or process is the ultimate success of the innovation process (Palmberg, 2002). Therefore, the success of the inventors have been measured by the measurements based on innovation process objective outcomes such as patent grants, awards and rewards, product development, commercialization, market share and finally the profit (Webster \& Jensen, 2009; Hauschildt, 1991). Hence, the social and psychological aspect of technology inventors and inventive activities were drastically omitted from the evaluation of the intellectual property and success of inventors (Mandel, $2011)$.

Owing to the over commercialization of inventive activities, the independent inventors are also considered as a group that have pure entrepreneurial and economic objectives. However, the explicit performances of independent inventors as entrepreneurs in both industrial and developing countries are not very encouraging. Especially due to the overdriven foreign direct investments, the independent inventors in developing countries have rapidly falling behind the achievements of elite employed inventors in multinational cooperation and research institutions (Giummo, 2010; Agrawal, Kapur, McHale, \& Oettl, 2011 ). However during the last decade, numbers and influences of independent inventors in local innovation systems in developing countries like Sri Lanka have continuously increased (Wickramasinghe, Ahmad, Rashid, \& Emby, 2010).

The controversial growth of the independent inventors in the developing societies has raised a question on the validity of existing inventor success measurements. It has created considerable doubt of keep using objective innovation process outcomes as the only measurements of success of independent inventors (Wickramasinghe, Ahmad, Rashid, \& Emby, 2011). These measures were unable to explain why independent inventors are involving in inventive activities while they are facing failures. Lack of understanding of socio-psychological aspect of inventing has become a serious obstacle to answer the question of whether 
the independent inventors are also looking for only entrepreneurial objective outcomes as the elite inventors in organizations. If the inventors continuously involve in inventive activities while they are experiencing failures, there should be some internal trait or state of mind that stimulated by inventive activities and encourage the inventors to continuously involve in inventive activities even when the environment not showing favorable conditions on them (Simonton, 2009). However, so far there is no specific attention given to explore the potential psychological aspect of success search by independent inventors from their inventive lives. Number of previous studies has discussed the intrinsic and extrinsic motives of inventors as the predictors of their inventive activities (Owan \& Nagoka, 2011 ; Bhaduri \& Kumar, 2010). However, these studies were unable to explain socio-psychological variables as the subjective outcomes of the inventive activities. The aim of this paper is to explore how the objective outcomes and subjective outcomes of inventive activities influence on the subjective success of the independent inventors in Sri Lanka.

\section{Background of the Study}

According to the literature, independent inventors achieve lower inventive success than the employed inventors (Dahlin, Taylor, \& Fichman, 2004). In general, recent patent and commercial success of the independent inventors in industrial countries has been very modest (Invention Statistics, 2009). These independent inventors were unable to compete with the growing business interest of inventions and often have recognized as leisure time hobby inventors who were not successful in modernized inventive activities. According to the available statistics of success of the independent inventors, less than 10 percent of the inventions have achieved the commercial success (Astebro, 1998). Owing to the unbearable change of interest in inventive activities, some commentators have expected the end of the independent invention in the world (Schumpeter, 1942; Scotchmer, 2004). In a society that recognized the commercial success as the ultimate interest of the technological inventors, it is rational to expect independent inventors not to be involved in inventive activities when seen the 90 percent failure rate in front of them. However, the independent inventors have never stopped the inventive activities. Even today there are high proportions of independent patent applications in the industrial societies (IFIA, 2006). 
Owing to the extremely gradual technological development and small numbers, neither the independent inventors nor their success in developing countries has been given acceptable attention (Mahmood \& Singh, 2003). In the developing countries number of independent inventors would be much higher, but they were never explored as in industrial countries (Weick \& Eakin, 2005). Even though the statistics are not readily available, majority of the patent applicants in developing countries are the independent inventors. Hence, the local innovation systems in the lower and middle income developing countries heavily depend on the shoulders of the independent inventors (UNDP, 2001; Weick \& Eakin, 2005; IFIA, 2006). Especially in Sri Lanka, 85 percent of the recent resident patent applications have been forwarded by the independent inventors (Table $01)$.

Table 1: Resident Patent Applications in Sri Lanka -2000-2008

\begin{tabular}{|l|c|c|c|c|c|c|c|}
\hline Year & $\begin{array}{c}\text { Research } \\
\text { Institutes }\end{array}$ & University & Business & $\begin{array}{c}\text { Non- } \\
\text { Resident }\end{array}$ & $\begin{array}{c}\text { Independent } \\
\text { Inventors }\end{array}$ & Total & $\begin{array}{c}\% \text { of } \\
\text { Inventors } \\
\text { Inventions }\end{array}$ \\
\hline 2000 & 5 & 2 & 9 & 1 & 52 & 69 & $75 \%$ \\
2001 & 7 & 1 & 12 & 1 & 92 & 113 & $81 \%$ \\
2002 & 11 & 6 & 12 & 1 & 69 & 99 & $70 \%$ \\
2003 & 13 & 5 & 11 & 1 & 50 & 80 & 62.5 \\
2004 & 4 & 6 & 14 & 0 & 82 & 106 & $77 \%$ \\
2005 & 10 & 6 & 16 & 0 & 113 & 145 & $78 \%$ \\
2006 & 13 & 12 & 14 & 0 & 121 & 160 & $76 \%$ \\
2007 & 7 & 7 & 15 & 1 & 123 & 153 & $80 \%$ \\
2008 & 9 & 6 & 14 & 2 & 170 & 201 & $85 \%$ \\
\hline Total & 79 & 51 & 117 & 7 & 872 & 1126 & $77 \%$ \\
\hline
\end{tabular}

Adapted from: Sri Lanka National Intellectual Property Office 2008

With the recent technological developments in neighboring developing countries in Asia, especially in Sri Lanka, grassroots level inventive activities have grown rapidly (National Intellectual Property Office, 2008). Further, throughout last decade, average of 77 percent resident patent applications in Sri Lanka has been forwarded by the independent inventors. Hence, unlike the industrial countries, in developing countries like Sri Lanka virtually entire technological knowledge creation and product development depend on the small scale 
grassroots level independent inventors. However, owing to the general preconception of the lower commercial success, acceptable level attention has never given to study the behavior of these inventors.

The conflict of objective measurements vs. subjective interests are clearly explicit among the growing independent inventors in developing countries like Sri Lanka where technological development has not been the stronghold in the society. Recently popularized positive psychological explanation of subjective happiness and satisfaction with life are capable of explaining the subjective aspect of success that might be significantly influenced by the inventive outcomes of the independent inventors. However, the studies in technological innovations have never given adequate attention to unseal the power of psychological success of inventors as an ultimate outcome of their inventive life.

\section{Positive Psychological aspect of Subjective Success}

Recent developments in subjective measures of happiness, satisfaction and wellbeing have developed a new psychological discipline called positive psychology that has questioned the validity of using only objective measures to explain the success. One person can feel success for an outcome, but the same outcome can be an unpleasant experience to another (Bartolome \& Evans, 1990). Sometimes people have wealth but need to sacrifice happiness and satisfaction of their lives to achieve it. They are not feeling happiness and hence, not achieve the subjective success. On the other hand, some people do not have wealth, but feel the happiness of their lives and hence achieve the subjective success. Differences in subjective definitions of the individual goals, objectives and desired outcomes, influence to the differences in subjective meaning of the success.

In modern capitalistic societies, success is explained by the objective perspective that measured the success based on predefined measures of the external outcomes that can be verified and observed by the third parties (Gunz \& Heslin, 2005). The high level of economic wealth and status has been the criteria to define a successful person. Descriptions of successful people often based on their physical wealth and assets. However, it is well known that what some people see as success in the sense of a good outcome, can be quite opposite to 
others (Tracy, 1989). People's behavior is often guided by their beliefs about the types of things that will make them happy (Gilbert, 2006). Even though the external world set standards and criteria to measure the successful behaviors and outcomes (objective success), the real feeling of success is determined by happy and satisfied feeling that the person's self-regulation system perceived apart from the objective outcomes. Not all the people in the world have same thinking about the happiness. Therefore it is meaningless to measure the success using pure objective measures. As per the philosophical literature of Aristotle, objective indicators do not necessarily mean the individual's success (Kenny, 2002). Therefore, the extensive use of standard measures to measure the success and satisfaction of human beings has been worthless.

Aristotle explains the philosophical concept of "eudemonia" as the ultimate aim of the human existence (Kenny, 2002). Even though eudemonia translated to happiness of life and pleasant well-being, according to the explanations most appropriate definition should be the "success", but it is subjective (Lear, 2009). Hence the subjective success consists of emotional and cognitive utilities that are only identifiable with introspection, and not by observation or verification (Snyder \& Lopez, 2007). By definition, subjective success is an individual self-evaluation of his or her feeling of happiness and satisfaction. As far as general norm of the success depicts the achievement of something desired, planned or attempted, the subjective success is the perceived positive emotional and cognitive feeling of the outcome of an event, incident or activity. In literature, there are some of the elements identified as indicators of subjective success, pride in achievement, intrinsic satisfaction, self-worth, and commitment to work, fulfilling relationships and moral satisfaction (Nicholson \& Andrews, 2005, pp. 141-142). However, as per the Dinner's explanations, these indicators measure the intermediate status of mind that lead to ultimate subjective success of life satisfaction and happiness (Diener E. , 2009 a). Satisfaction of life and happiness are the measures of the "bottom line" impact of the consequences of life (Andrew \& Robinson, 1991).

Individual's self-assessment of subjective life satisfaction and happiness developed as a self-regulatory rational of positive and negative feeling of their life activities and incidences. In positive psychology literature, these subsections of life activities and incidences defined as life domains and 
individuals have different life domains that generate positives and negatives of their overall life satisfaction and happiness (Rojas, 2006). Persons' family life, work life, economic status, social life and leisure life consists with the different life domains and satisfaction with specific domain provide some weight to the subjective success of the life. Therefore, domain satisfaction needs to be defined as a predictor of the subjective success of life that has been measured by overall or global subjective life satisfaction and happiness. As per the available literature on Grassroots level inventors, the majority of them are involved in inventive activities either as part time employee activity (Wieck \& Martin, 2006) or leisure time activity (Dahlin, Taylor, \& Fichman, 2004). It makes the inventors' inventive activities and it's outcomes to be influential on different life domains that have roots to work life domain, leisure life domain and economic life domain. Therefore, objective outcomes and perceived satisfaction with the inventive domain of the life of the grassroots inventors might work as the predictor of their global subjective success.

\section{Conceptual Framework of the Study}

Extremely limited number of studies has raised the issues and limitations of the existing standardized objective success measurements on inventors such as patents, commercialization and profit for their universal applications to evaluate the success of every inventor (Livesay, Lux, \& Brown, 1996; Audia \& Goncalo, 2007). These studies have raised the valid questions over the existing objective measures of success, which were unable to explain, why independent inventors are continually involving in inventive activities, if they are not succeeding as the entrepreneurs. According to the bottom-up theoretical argument of subjective success, living happy and satisfied life is the ultimate aim of the human existence and it will drive the people to behave in particular manner (Diener, 2009 b). Hence, the involvement in challenging activities and gaining positive objective and subjective achievements from them expected to be positively influence to the subjective success of life of people. Inventors not only achieve objective outcomes such as patents, rewards, commercialization and profit. But also involving in interesting and challenging inventive activities and receiving objective outcomes their inventive career satisfaction and connectedness to the inventive community are also expected to be strengthen. The conceptual framework of 
the present study aims to explore how the extrinsic (objective) and intrinsic (subjective) outcomes of inventive life have influenced on the subjective success of the independent inventors in Sri Lanka (Figure 1).

\section{Figure 1: Conceptual Framework of the Study}

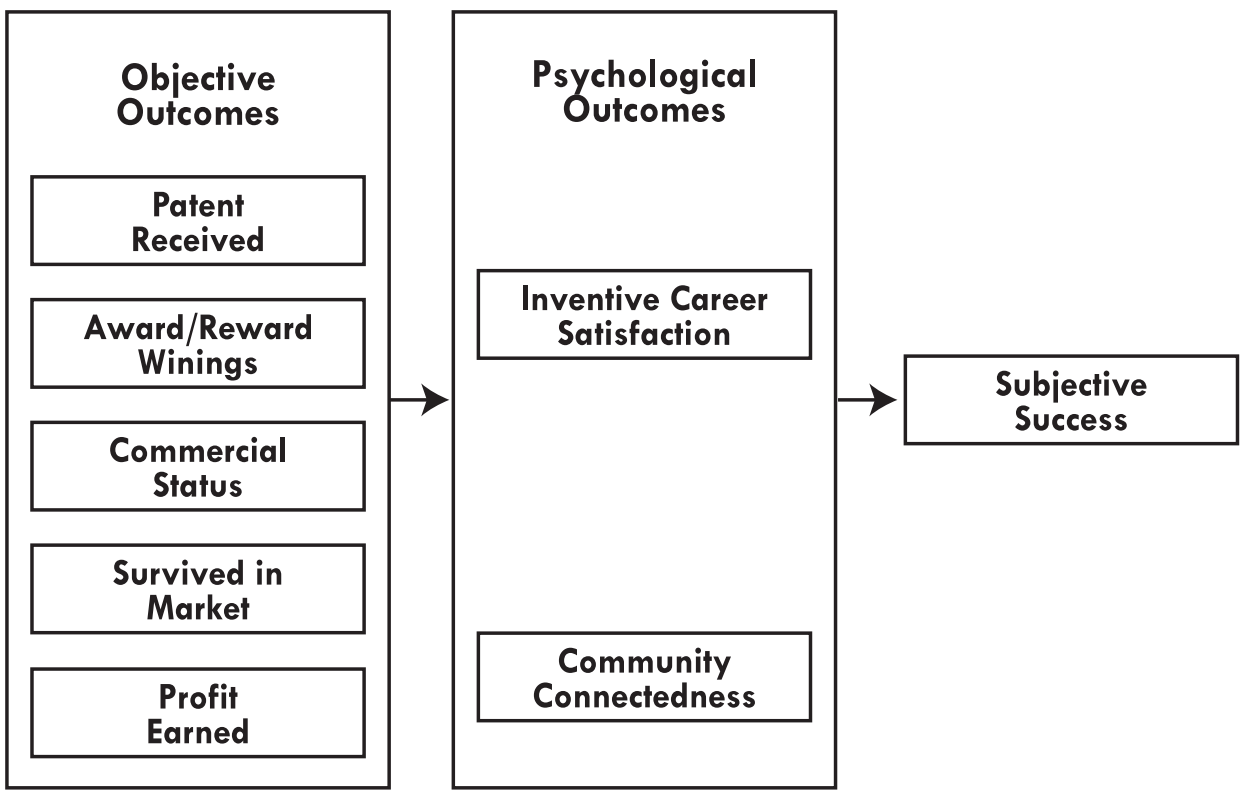

\section{Methodology}

Even though all the inventors are not applied for patents, patent databases has been recognized as the only available central depository of the innovation skills of a nation (Jaffe, Trajtenberg, \& Romer, 2002; Koch, 1991). Hence, the researchers searched the Sri Lanka National Intellectual Property Office (SLNIPO) patent database for the independent inventors who applied for the patents during the year 2000-2009. Researchers were able to identify 640 independent inventors as the target population of the study. Even though 640 is a small number, inventors were scattered throughout 24 districts covering $65,610 \mathrm{KM}^{2}$ in Sri Lanka. Therefore the researchers selected 200 inventors using stratified random sampling technique, by stratifying the population based on their living districts. Sample represented the 31 percent of the target population. The required data was collected by self administrative questionnaire 
method through the Sri Lanka Independent Inventors Survey (SLIS 2010), which was carried out by the researchers from the month of February to August 2010.

\section{Profile of the Respondents}

Table 2 presents the selected demographic profile of the sample. According to the table 2, majority of the respondents are middle aged males. Two-third of the respondents married and 60 percent of the respondents were having either vocational or university level education. Majority of the respondents were freelance employees who have freedom of choice about what they are doing. Two -third of the respondents represented the rural areas of the Sri Lanka, where according to the existing classification, 80 percent of the country population is rural.

Table 2: Demographic profile of the respondents

\begin{tabular}{|c|c|c|c|c|c|}
\hline & Frequency & $\%$ & & Frequency & $\%$ \\
\hline Age & & & Education & & \\
\hline $10-18$ & 10 & 5.0 & School & 80 & 40 \\
\hline $19-30$ & 43 & 21.5 & Vocational & 34 & 17 \\
\hline $31-40$ & 45 & 22.5 & Lower Tertiary & 65 & 32.5 \\
\hline $41-55$ & 60 & 30.0 & Post graduate & 21 & 10.5 \\
\hline $56-65$ & 36 & 18.0 & Employment Sector & & \\
\hline $65+$ & 6 & 3.0 & Government & 34 & 17 \\
\hline Gender & & & Private & 77 & 38.5 \\
\hline Male & 190 & 95 & Non Government & 01 & 0.5 \\
\hline Female & 10 & 5 & Freelance & 88 & 44 \\
\hline Marital Status & & & Location & & \\
\hline Married & 135 & 67 & Rural & 128 & 64 \\
\hline Unmarried & 65 & 33 & Urban & 72 & 36 \\
\hline
\end{tabular}

Demographic factors of the respondents in the sample, such as age, gender, marital status, education and employment status were fairly similar with the past studies on independent inventors in industrial countries. Majority of those studies found that average independent inventor is a middle aged married male who has high level of education qualifications and involved in freelance economic activities (Sirilli, 1987; Amesse \& Desranleau, 1991; Weick \& Eakin, 2005; Georgia Tech Enterprise innovation Institute, 2008). However, past studies have identified that majority of the independent inventors are living in metropolitan areas rather than rural areas. Urban and rural classification in 
Sri Lanka has been based on the size of the lowest political administrates of the country. But in most of the industrial countries it has been based on the density of the population (United Nations, 2007). Apart from the differences occurred due to this classification, Sri Lankan independent inventors those who represent the sample have shown similar demographic profile as the independent inventors in the industrial countries. Hence, sample of the present study is a representative cross-section of the general independent inventors' community.

\section{Measurements}

\section{Objective outcomes}

Different inventors search for different benefits and outcomes from their inventions. Hence, the expected inventive outcomes can be vary from inventor to inventor and there was no standardized measurement to measure the success of the inventors. However, majority of the available inventor's objective success measures have been patent related and commercial success measures. Even though the inventors' success has been measured by singular measurements, from idea generation to successful commercialization, inventions need to go through number of different stages. Hauschildt (1991) had explained the importance of measuring the success of innovation at different stages of innovation process. According to him not every invention is going through all different stages of the innovation process. Therefore, measuring the success of inventors only by patent or commercialization measurements is not showing the reality of the success. Adhering to Hauschildt framework and diverse desires of inventors, present study has adapted five different objective measurements to measure the inventors' success at each stage of the innovation process: Idea generation stage by patent receives, competitive evaluation stage by award, reward and promotion winnings, market entrance stage by commercialization, market survival stage by survival in market and income earning stage by profit earned. To eliminate the influence of differences of number of inventions among the inventors, following the Weick \& Eakin (2005), the researchers adopted a dichotomous scale by asking the questions on whether the inventors have at least single invention achieved success at each stage and received the answer as yes or no. When the inventor had at least one invention that satisfies the criteria of each question, they were considered as success at the respective 
stage of the innovation process. It not only considered the latest patent applied invention, but also considered the inventions developed throughout the inventive life of the inventor.

\section{Subjective Outcomes}

Apart from the objective outcomes, every intentional human activity has psychological or intrinsic feelings connected to it. In motivational literature intrinsic factors has been identified as a better measurement of the external control and self regulation of people (Ryan \& Deci, 2000). Even though, significant attention was not given in recent literature on industrial inventors, the psychological factors related to the inventors have been identified as significant motives among the grassroots level inventors (Bhaduri \& Kumar, 2010). Present study has identified psychological and socio-psychological subjective outcomes of inventive life: Inventive career satisfaction and Sense of community as potential predictors of the global happiness and satisfaction of their lives.

Career satisfaction is one of the most enduring psychological construct in the study of industrial relations. Many commentators have explained the concept with different names as job satisfaction, work satisfaction. Job satisfaction is generally defined as the extent to which people like (satisfaction) or dislike (dissatisfaction) their jobs (Spector, 1997, p. 2). Greenhaus et. al. (1990) defined the career satisfaction as the satisfaction of a person towards the successful outcomes of their work life (Greenhaus, Parasuraman, \& Warmley, 1990). Present study defines the inventive career satisfaction as the inventor's psychological assessment of the overall characteristics and outcomes of the inventive activities of his or her inventive life. Macdonald and Macintyre (1997) have developed ten items scale based on the definition of job satisfaction is determined by the psychological reactions to the characteristics of the job (Macdonald \& Macintyre, 1997). The ten items cover the feelings of social recognition, supervision, job security, benefits, skill utilization and overall interest of the job. The scale had shown high validity and reliability and applicable in different work situations without modifications. Independent inventing is a freelance career activity and therefore, the six items of the scale were unable to directly apply to measure the grassroots level inventors career success. Therefore researchers selected four items from the scale to be modified. 
Modification for these items was done by concerning the core satisfactions suggested by the Greenhaus et al (1990) career satisfaction scale. After the modifications the researcher has developed four items scale with five point Likert like responses ( $\alpha=.706$ ) to measure the career satisfaction; covering satisfaction with achievements, satisfaction with recognition, satisfaction with inventing, and willingness to continue the inventing.

$\alpha$

In literature sense of community and community connectedness has been used interchangeably. In general the concept is defined as the convergence of individuals' desires to belong to a community, establish a mutually influential relationship with that community, satisfy their individual needs and be rewarded through their collective affiliation, and construct a shared emotional connection (Whitelock, 2007; McMillan \& Chavis, 1986; Frost \& Meyer, 2009). According to the definition proposed by the McMillan and Chavis (1986) sense of community (community connectedness) is a feeling that members have of belonging, a feeling that members matter to one another and to the group, and a shared faith that members' needs will be met through their commitment to be together. Frost and Meyer's Community connectedness consists with 8items that adapted from a 7 -item community cohesion scale used in the Urban Men's Health Study (UMHS). They added one item "You feel a bond with other [men who are gay or bisexual]" taken from Herek \& Glunt (1995) community consciousness scale. Their study has shown high validity and Cronbach alpha internal consistent value (Frost \& Meyer, 2009). In present study Frost and Meyer's community connectedness scale was modified by replacing the specific words related to LGB community by words related to grassroots level inventive community. Even though the original Frost and Meyer's scale have only 4 likert like responses ( $1=$ strongly Disagree to $4=$ strongly agree) present study had used more optioned to describe the nature of the connectedness of grassroots level inventors. It suggested 7 point likert like scale $(\alpha=.822)$.

\section{Subjective Success}

According to the operational definition adopted in the present study, the subjective success is synonymous to the definition of the subjective well-being. According to the literature, definitions of the subjective well being consist with emotional aspect, which was mostly measured by the happiness and cognitive 
aspect, which was mostly measured by satisfaction with life. Subjective Happiness Scale (SHS) and Satisfaction with Life Scale (SWLS) are the most administrated scales to measure subjective success (Snyder \& Lopez, 2007; Diener E. , 2009 b). In order to measure both emotional and cognitive aspects of subjective success, integration the of Subjective Happiness Scale and Satisfaction With Life Scale was already practiced by the Lyubomirsky S. and therefore she recommended the researcher to use integrated scale in the present study (Lyubomirsky S, Personal Communication, 21 February 2010). Both the SHS and SWLS are available for free usage with copy left policy. In present study, Subjective success was measured using summation of original Subjective Happiness Scale-4 items (Lyubomirsky \& Lepper, 1997) and Satisfaction with Life Scale - 5 items (Diener, Emmons, Larsen, \& Graiffin, 1985). Hence, the subjective success scale was a seven point Likert like scale consisted with nine items $(\alpha=.777)$.

\section{Findings}

Prior to the multivariate data analysis, the researchers conducted descriptive analysis of the variables of the conceptual model. Summary of the descriptive analysis of the objective outcomes measures depicted in the radar diagram in figure 02. According to the figure number of successful inventors at the patenting and commercializing stages is higher than the inventors those who had not succeeded at those stages. Hence, the majority of inventors have achieved success in patent grant and initiating to commercialize their inventions. However, at the stages where inventors were contacted and evaluated by the external world, number of unsuccessful inventors was higher than the successful ones. There is higher number of inventors who have not had at least one award winning, market survived and profit earned invention. Therefore, majority of the respondent inventors were successful in front end inventive activities. However, when they entered to the back end activities that heavily depend on the interaction with the outside parties, they were struggling to be successful inventreprenuers. 
Figure 2: Achievement of Objective Success by the Respondents

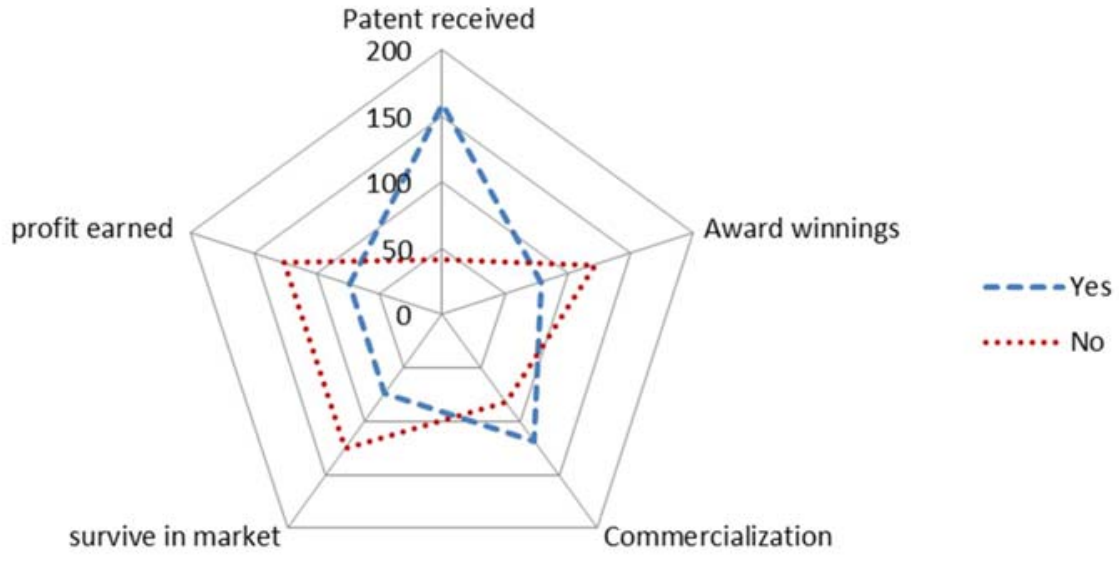

Contrast to the objective outcomes, the respondent inventors achieved relatively high level of subjective outcomes (Table 2). Mean score of the inventive career satisfaction is close to the high end of the scale $(M=16.235, S D=2.110)$. Further, more than 65.5 percent of the respondents achieved higher inventive career satisfaction.

Table 3: Descriptive Statistics of Socio-psychological Variables of the Study

\begin{tabular}{|c|c|c|c|c|c|}
\hline Variables & Mean & SD & Low & Medium & High \\
\hline $\begin{array}{c}\text { Inventive Career } \\
\text { Satisfaction }\end{array}$ & 16.235 & 2.110 & 0 & $69(34.5 \%)$ & $131(65.5 \%)$ \\
\hline $\begin{array}{l}\text { Community } \\
\text { Connectedness }\end{array}$ & 43.275 & 6.265 & 0 & $50(25 \%)$ & $150(75 \%)$ \\
\hline Subjective Success & 41.100 & 7.051 & $8(4 \%)$ & $139(69.5 \%)$ & $53(26.5 \%)$ \\
\hline
\end{tabular}

Then again, respondent inventors indicated high level of community connectedness $(M=43.275, S D=6.265)$. Three quarter of the respondents indicated sense of community scores higher than 40 . Findings of the inventive career satisfaction and community connectedness indicate that respondent inventors satisfied with their inventive life and they sense emotional attachment with other inventors and psychologically connected with the inventors as community. 
Descriptive analysis of subjective success indicated on average inventors achieved medium to high level of subjective success $(M=41.100, S D=7.051)$. In the sample 96 percent of the respondents have scored 28 or higher subjective success score, where the expected minimum score is 9 . Only 4 percent of the respondents scored the subjective success scores less than 28. Then again more than 25 percent of the respondents scored higher than 45, hence they showed relatively high level subjective success. The results further indicate that even though the majority of inventors have not achieved objective success in backend inventive activities, majority of them were subjectively successful inventors. Hence, in general average independent inventor in Sri Lanka is happy and satisfied with their life.

After conducting the descriptive analysis of the variables, the researchers conducted exploratory data analysis for the metric variables of the study and ensures that the variables are adhere to the assumptions of normality, linearity and Multicollinearity. After the testing for the required assumptions, multiple regression analysis was used to test whether the objective and subjective outcome variables of inventive life have significantly predict the subjective success of the respondent independent inventors. According to the regression analysis of the relationship between objective outcomes and inventive career satisfaction, none of the objective outcomes were important predictors of the variance inventive career satisfaction $\left(R=.246, R^{2}-.060, p=.032\right)$. Second regression analysis that considered objective outcomes as the predictors of community connectedness was not statistically significant $\left(R=.167, R^{2}=.028, p=.357\right)$ and again non-of the objective outcomes become the significant predictors of community connectedness. Hence, patent success, award winning success, commercialization success, survival success and profit earning success were unable to significantly predict either the inventive career success or the connectedness to the inventive community. Hence, the hypothesized mediation effects of inventive career satisfaction and the community connectedness were not supported by the regression results. The results indicated that inventive career satisfaction and connectedness to the inventive community are not determined by the innovation process outcomes of the independent inventors in Sri Lanka.

During the second stage of data analysis, the researchers modified the hypothesized conceptual model based on the initial regression results. 
Standardized regression coefficients of the modified conceptual method and their statistical significance presented in figure 03.

\section{Figure 3: Multiple Regression results of the Conceptual Model}

Objective Outcomes

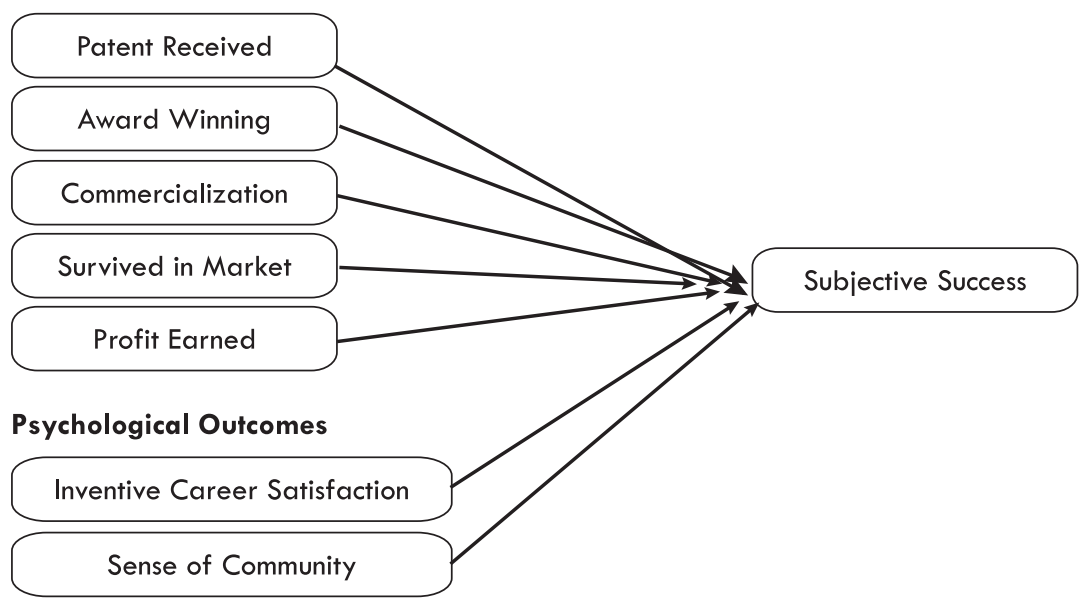

The results of the multiple regression indicated that objective and subjective predictor variables explained $47 \%$ of the variance of the subjective success $\left(\mathrm{R}^{2}=.465, \mathrm{~F}=23.863, \mathrm{p}<.001\right)$. According to the Cohen's effect size criteria (Cohen, 1988), $R^{2}$ has shown very large effect size $\left(f^{2}=.869\right)$. Results indicated that patent grants $(B=.069, p=.206)$ and winning of awards $(B=-.066, p=$ .234) have not been significant predictors of the subjective success of the independent inventors. Then again, even though the profit has been significant criteria of determining the success of innovation, regression results showed that profit earning from innovation have not a significant predictor of the subjective success of the inventors at .05 level $(\beta=.133, p=.062)$. Start to commercialize invention $(B=.419, p=.000)$ and survival in market $(B=-.187, p=.018)$ has been the significant objective outcome predictors of the subjective success of the inventors. However, survival in market had a negative influence on the subjective success of the independent inventors. Unlike objective outcomes, it was found that both inventive career satisfaction $(B=.317, p=.000)$ and sense of community $(B=.283, p=.000$ ) were significant positive predictors of the subjective success of the inventors. 


\section{Discussion}

This paper aims to contribute to the knowledge of technology in society by exploring how the extrinsic (objective) and intrinsic (subjective) outcomes of inventive life have influenced on the subjective success of the independent inventors in Sri Lanka. Initial analysis of demographic profile of the respondents indicated the homogenous nature of the independent inventors as middle aged married males with high education levels. Findings of the studies on independent inventors in industrial countries also have shown similar demographic profiles (Georgia Tech Enterprise innovation Institute, 2008; Amesse \& Desranleau, 1991; Weick \& Eakin, 2005). Hence, irrespective of the external environment, independent inventors in industrial countries and developing country like Sri Lanka share common demographic characteristics that make them to be the members of the global community of independent inventors. Majority of the independent inventors in Sri Lanka also were unable to succeed in the backend innovation process activities that involved the successful commercialization and profitability. Showing the similar trend, in general objective success of independent inventors in industrial countries also has not been very high (Invention Statistics, 2009). However, in industrial countries independent inventors have invented a large number of breakthrough inventions (Dahlin, Taylor, \& Fichman, 2004). Hence, they have received respect, social support and attention than the inventors in developing countries (Weick \& Eakin, 2005). Therefore, total ignorance and discrimination of independent inventors in developing countries should be stopped and when the environment makes favorable and opportunities are given, independent inventors can be the significant contributors of the technology development in the middle income developing countries like Sri Lanka.

According to the bottom-up positive psychological theories happiness and satisfaction of life is the ultimate state of mind that people can achieve from their sub domains of life (Diener, 2009 b). Previous studies on motivation of inventors have considered psychological factors only as predictors of their involvement in inventive activities (Bhaduri \& Kumar, 2010). Until the present study, there is hardly any study considered the happiness and satisfaction of life as the ultimate aim of the inventors. Finding of the present study indicates that the most of the independent inventors in Sri Lanka are generally happy 
and satisfied group of people. According the Fredrickson (2004) broaden and build theory of positive emotions, happy and satisfied people can have the high level of psychological and social resources than the unhappy and unsatisfied people. Higher levels of happiness and satisfaction of the independent inventors might broaden and build of existing and new internal skills and resources of their lives. Hence, happiness and satisfaction of life might drive the inventors to believe themselves and be optimistic about their inventive activities even the existing objective outcomes are not very encouraging. Their hope to succeed in the future might be a factor that influence on their inventive activities than the actual objective outcomes of the inventive process.

Traditionally the technological inventions have been considered as the process that aims the objective outcomes. However, findings of the present study explained the inventive career satisfaction and sense of inventive community of independent inventors as subjective outcomes of the inventive activities rather than its outcomes. According to the results of initial model analysis, objective inventive process outcomes were weak predictors of inventive career satisfaction and community connectedness. The world most renowned independent inventor, Thomas Edison once said that "one might think that the money value of an invention constitutes its reward to the man who loves his work. But I continue to find my greatest pleasure, and so my reward, in the work that precedes what the world calls success". Hence, independent inventors seem to be emotionally attached to the innovation process rather than the outcome. For independent inventors, invention is a way of life than the entrepreneurial activity and hence, over evaluation them based on their objective outcomes might be counterproductive and discouraging in less technologically developed societies like Sri Lanka.

Further, the present study explored how the objective outcomes and subjective outcomes of inventive activities relate to the happiness and satisfaction of the life of the inventors. Finding of the modified model of the study suggests that the survival in market is negatively influence on the subjective success and profitability not significantly contribute to the subjective success. These findings suggest that taking the inventions to the market is a psychological hindrance for the independent inventors. Owing to the rapid growth of the capitalistic economic models, attention given to the independent inventors has shifted to 
elite business organization (Scotchmer, 2004). Unlike independent inventors, employed inventors have required physical and human resources to develop the raw inventive ideas to winning product. However, independent inventors have to do everything by their own (Meyer, 2005). Hence, independent inventing has been discriminated in the world and owing to the habitual technological dependency in developing countries environment might be very hostile for independent inventors. High level of inventive career satisfaction, sense of community and their significant influence on the subjective success indicates that commercialization is not a significant decision criterion for the independent inventors in Sri Lanka to decide the continuation of their inventive lives.

If the inventors are involved in inventions only to achieve objective outcomes of the inventive activities, independent inventors should have dead and buried long time ago as expected (Schumpeter, 1942). However, findings of the study indicate that irrespective of the objective outcomes of the inventive life, majority of the inventors in Sri Lanka satisfied with their inventive careers. Hence, the motivation of the independent inventors can be found within themselves than the external outcomes of the inventive activities. Finding of high sense of community among the inventors in Sri Lanka indicates that involvement of inventive activities not only create satisfaction within the inventors, it also influence to create emotional bond between the inventors as a stronger community. The high sense of community might motivate them to keep involving in inventive activities when they see or hear success stories of inventors of their kind. As far as the inventive career satisfaction and sense of community are significant predictors of subjective success, it will continue to increase the happiness and satisfaction of life of the inventors. Then again it will broad and builds the skills and resources of the inventors to continue in inventive activities. Therefore, independent inventors are subjectively driven than the objective driven. This process might continues as cycle within the independent inventors and this might be a one reason for continuous increase of independent inventive activities in countries like Sri Lanka and also around the world. 


\section{Conclusion}

According to the findings of the study, objective outcomes of inventive process where the inventors need to largely depend of third party evaluations such as award winnings and survive in the market negatively influence on the subjective success. Owing to the unfavorable environment on independent inventors they need to go though exhausting processes to succeed in these outcome stages of their inventions. It might take them away from their natural lives and sometimes it destroys the natural nature of their lives. These changes may negatively influence on their happiness, satisfaction of life and even survival of their own life can be challenged as the story of Rudolf Diesel, the inventor of the diesel engine. Therefore, this study concludes that the subjective outcomes and subjective success of lives of independent inventors are significant socio-psychological states of their mind that positively influence on the growth of their involvement in inventive activities. Findings of the study suggest significant policy implications in developing countries like Sri Lanka to develop policies to make use of the independent inventions for national technological development. It is expected to conduct more future studies on psychological aspect of success in developing countries to find specific motives to encourage independent inventors to involving in demanding areas in technological innovations. Owing to the fact that independent inventors are more sensitive to the subjective outcomes rather than objective outcomes, governments need to provide incentives to the business community take over the inventions from the inventors at the back-end inventive processers. It would reduce the burden and unhappy experiences of the inventors and make them feel happy and satisfied with their inventive lives. That would allow them to be more focus on developing inventions, which will make them happy and satisfied with their lives rather than doing exhausted business activities. This collaborative approach of the innovation system would provide win-win situation for all its stake holders and would gradually improve the technological development in low and middle income countries. 


\section{References}

Agrawal, A., Kapur, D., McHale, J., \& Oettl, A. (201 1). Brain drain or brain bank? The impact of skilled emigration on poor-country innovation. Journal of Urban Economics, 69 (1), 43-55.

Amesse, F., \& Desranleau, C. (1991). The independent inventor and the role of entreprenurship: A survey of the canadian evidence. Reserach policy, 13-27.

Andrew, F. M., \& Robinson, J. P. (1991). Measures of Subjective Well-being. In J. P. Robinson, P. R. Shaver, \& S. W. Lawrence, Measures of personality and social psychological attitudes (pp. 61-114). San Diago: Academic Press.

Astebro, T. (1998). Basic statistics on the success rate and profit for independent inventors. Enterprenuership, Theory and practice , 23 (2), 41-48.

Audia, P. G., \& Goncalo, J. A. (2007). Past Success and Creativity over Time: A Study of Inventors in the Hard Disk Drive Industry. Management Science , 53 (1), 1-15.

Bartolome, F., \& Evans, P. A. (1990). Must success cost so much. In H. Levinson, Designing and Managing Your Career (pp. 305-316). Boston: Harvard Business School Publishing.

Bhaduri, S., \& Kumar, H. (2010). Extrinsic and intrinsic motivations to innovate: tracing the motivation of 'grassroot' innovators in India. Mind \& Society, Online First, 1 29.

Cohen, J. (1988). Statistical Power Analysis for the Behavioral Sciences. New Jersey: Lawrence Erlbaum Associates Inc.

Dahlin, K., Taylor, M., \& Fichman, M. (2004). Today's edisons or weekend hobbyists: Technical merits and success of inventions of independent inventors. Research policy , 2004 (33), $1167-1183$.

Diener, E. (2009 b). Subjective Well being. In E. Diener, The Science of well-being the collected works of Ed Diener (pp. 1 1-58). BV: Springer.

Diener, E. (2009 a). The Science of well-being the collected works of Ed Diener. BV: Springer.

Diener, E., Emmons, R. A., Larsen, R. J., \& Graiffin, S. (1985). The satisfaction with life scale. Journal of Personality Assessment , 49 (1), 71-76.

Fredrickson, B. L. (2004). The broaden-and-build theory of positive emotions. The Royal Society, 359, 1367-1377. 
Frost, D. M., \& Meyer, I. H. (2009). Internalized Homophobia and Relationship Quality among Lesbians, Gay Men, and Bisexuals. Journal of counseling psychology, 56 (1), 97-109.

Georgia Tech Enterprise innovation Institute. (2008). 2007 survey of Georgea's Independent Inventors. Altanta: Georgia Tech Reserach Corparation.

Gilbert, D. (2006). Stumbling on happiness; Think you know what makes you happy. New York: Knopf.

Giummo, J. (2010). German employee inventors' compensation records: A window into the returns to patented inventions. Research Policy, 39 (7), 969-984.

Greenhaus, J. H., Parasuraman, S., \& Warmley, W. M. (1990). Effects of Race on Organizational Experiences, Job Performance Evaluations, and Career outcmes. The Academy of Management Journal , 33 (1), 64-86.

Gunz, H., \& Heslin, P. A. (2005). Reconceptualizing career success. Journal of Organizational Behavior, 26, 105-111.

Gurdon, M. A., \& Samsom, K. J. (2010). A longitudinal study of success and failure among scientist-started ventures. Technovation , 30 (3), 207-214.

Hall, D. T., \& Chandler, D. E. (2005). Psychological Success: When the career is calling. Journal of Organizational Behavior, 26, 155-176.

Hauschildt, J. (1991). Towards measuring the success of Innovations. In D. F. Kocaoglu, Technology Management : the New International Language (pp. 605-608). IEEE Xplore.

Headey, B., Holmstrom, E., \& Wearing, A. (1984). THE IMPACT OF LIFE EVENTS AND CHANGES IN DOMAIN SATISFACTIONS ON WELL-BEING. Social Indicators Research , 15, 203-227.

IFIA. (2006, 05 16). Independent inventors Statistics. Retrieved 10 24, 2009, from International federation of Invetors' Association: http://www.invention-ifia.ch/ independent_inventors_statistics.htm

Invention Statistics. (2009). Invention Success Rates | Odds of Inventor Success. Retrieved February 26, 2011, from www.inventionstatistics.com: http:// www.inventionstatistics.com/Innovation_Risk_Taking_Inventors.html

Jaffe, A. B., Trajtenberg, M., \& Romer, P. M. (2002). Patents, citations, and innovations: a window on the knowledge economy. Massachusetts: MIT press. 
Kenny, A. (2002). Aristotle on the Perfect Life. New York: Oxford University Press.

Koch, A. (1991). Patent information to stimulate innovation in small and medium sized companies. World Patent Information , 13 (4), 201-205.

Lamoreaux, N. R., \& Sokoloff, K. L. (2005). The Decline of the Independent Inventor: A Schumpterian Story? NBER Working Paper No. $11654,1-51$.

Lear, G. R. (2009). Happiness and the Structure of end. In G. Anagnostopoulos, A companion to Aristotle (pp. 387-403). Oxford: Blackwell Publishing.

Lemley, M. A., \& Sampat, B. N. (2008). Is the Patent Office a Rubber Stamp? Emory Law Journal , $58(1), 181-206$.

Linstone, H. A. (2011). Three eras of technology foresight. Technovation , 31 (2-3), 69-76.

Livesay, H. C., Lux, D. S., \& Brown, M. A. (1996). Human factors and the innovation process. Technovation , $16(4), 173-186$.

Lyubomirsky, S., \& Lepper, H. S. (1997). A Measure of subjective happiness: priliminary relaibility and construct validation. Social Indicator Research (46), 137-155.

Macdonald, S., \& Macintyre, P. (1997). The Generic Job Satisfaction Scale: Sacle Development and Its Correlates. Emplyee Assistance Quarterly, 13 (2), 1-15.

Mahmood, I. P., \& Singh, J. (2003). Technological dynamism in Asia. Research Policy, $32,1031-1054$.

Mandel, G. N. (2011). To Promote the Creative Process: Intellectual Property Law and the Psychology of Creativity. Notre Dame Law Review, 1-25.

McMillan, D. W., \& Chavis, D. M. (1986). Sense of Community: A Definition and Theory. Journal of Community Psychology, 14, 6-23.

Meyer, M. (2005). Independent inventors and public support measures: insights from 33 case studies in Finland. World Patent Information, 27(2005), 113-123.

National Intellectual Property Office. (2008, 5 23). Patent Statistics 2008. Patent statistics database. Colombo, Sri Lanka: NIPO.

Nicholson, N., \& Andrews, W. W. (2005). Playing to win: Biological imperatives, Selfregulation, and trade offs in the game of career success. Journal of Organizational Behavior, 137-154.

Owan, H., \& Nagoka, S. (2011). Intrinsic and Extrinsic Motivation for Inventors. RIETI Discussion Paper Series 11-E-022, 1-51. 
Palmberg, C. (2002). Successful innovation; The determinants of commercialisation and break-even times of innovations. Vuorimiehentie: VTT Technical Research Centre of Finland.

Quillen, J. ,., \& Webster, O. H. (2009). Continuing Patent Applications and Performance of the U.S. Patent and Trademark Office - One More Time. The Federal Circuit Bar Journal , 18 (3), 379-404.

Rojas, M. (2006). Life Satisfaction and Satisfaction in Domains of Life: Is it a Simple or a Simplified Relationship? Journal of Happiness Studies , 7 (4), 467-497.

Ryan, R. M., \& Deci, E. L. (2000). Intrinsic and Extrinsic Motivations: Classic Definitions and New Directions. Contemporary Educational Psychology , 25 (1), 54-67.

Schumpeter, J. M. (1942). capitalism, socialism and Democracy. New york: Harper \& Row.

Scotchmer, S. (2004). Innovation and Incentives. London: The MIT press.

Shavinina, L. V. (2003). The international handbook on innovation. New York: Pergamon.

Simonton, D. K. (2009). Genius 101. new York: Springerlink.

Sirilli, G. (1987). Patents and inventors: An empirical Study. Research policy, pp. $157-174$.

Snyder, C. R., \& Lopez, S. J. (2007). Postive Psychology: the scientific and practical explorations of human strangths. California: Sage Publications Inc.

Spector, P. E. (1997). Job Satisfaction: Application, Assessment, Causes, and Consequences. New York: Sage Publications.

Tracy, B. (1989). Psychology of Success. Califonia, USA: Nightingale-Conant .

UNDP. (2001). Human Development Report 2001: Making new technologies works for human development. New York: Oxford University Press.

United Nations. (2007). Demographic Yearbook 2007. New York: Department of Economic and Social Affairs, United Nations.

Wanous, J. P., Reichers, A. E., \& Hudy, M. J. (1997). Overall Job Satisfaction: How Good Are Single-Item Measures? Journal of Applied Psychology, 82 (2), 247 252.

Webster, E., \& Jensen, P. H. (2009). Do Patents Matter for Commercialization? Intellectual Property Research Institute of Australia Working Paper No. 03/09, 1-35. 
Weick, C., \& Eakin, C. F. (2005). independent Inventors and innovation: An empirical study. Entrepreneurship and innovation, 5-15.

Whitelock, J. (2007). The role of adults, public space, and power in adolescent community connectedness. Journal of Community Psychology, 35, 499-518.

Wickramasinghe, C. N., Ahmad, A., Rashid, S., \& Emby, Z. (2010). Re-establishing Grassroots Inventors in National Innovation System in Less Innovative Asian countries. In S. Chu, W. Ritter, \& S. Hawamdeh, Managing Knowledge for Global and Collaborative Innovations (pp. 67-80). Singapore: World Scientific.

Wickramasinghe, C. N., Ahmad, N., Rashid, S., \& Emby, Z. (2011). Impact of Subjective Well-Being on Success of Technological Knowledge Creation among Independent Inventors in Developing Countries: A First Look at Sri Lanka. Journal of the Knowledge Economy, Online First.

Wieck, W. C., \& Martin, J. D. (2006). Full-time and part-time independent inventors Rising with the creative class. Entrepreneurship and Innovation, 5-12.

Williams, J. (2004, May 22). Job satisfaction and organizational commitment. Retrieved September 25, 2010, from Solan Work and Family Research Network: http:// wfnetwork.bc.edu/encyclopedia_entry.php?id=244 